\title{
Reconciling surface and groundwater models in a climate change context
}

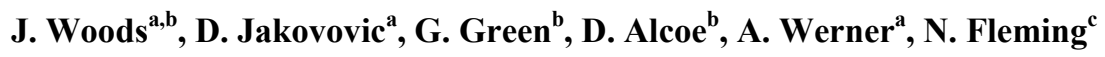 \\ ${ }^{a}$ National Centre for Groundwater Research and Training, Flinders University, South Australia \\ ${ }^{b}$ Department of Environment, Water and Natural Resources, South Australia \\ ${ }^{c}$ South Australian Research and Development Institute \\ Email: juliette.woods@flinders.edu.au
}

\begin{abstract}
To understand the possible impacts of changes in rainfall and potential evapotranspiration (PET) in a river catchment in which surface water and groundwater systems are connected, the dynamic interaction that exists between changes in surface runoff, groundwater recharge, and groundwater levels must be represented appropriately. While such a system can be modelled using fully coupled groundwater-surface water flow models, it is more common for separate specialised models to be developed independently by different teams for different purposes. The assumptions, parameters and outputs of the models are not compared.
\end{abstract}

This paper develops a methodology for comparing specialist hydrological models commonly used in Australia to simulate catchment processes. Three models were developed, initially independently, of the Cox Creek sub-catchment in the Mount Lofty Ranges of South Australia: a LEACHM model of groundwater recharge, a SOURCE model of surface water runoff, and a MODFLOW model of groundwater flow. The models are reconciled by using multiple outputs of the LEACHM model as inputs to the MODFLOW model, and calibrating the MODFLOW model to SOURCE outputs. Reconciliation of the inputs and outputs of the three models with each other should improve the rigour in each model's simulation of catchment processes. The reconciled models will be run with stochastically-generated input data sets of rainfall and PET, representing a variety of possible future climate scenarios generated by one of the CMIP5 group of global climate models. Reconciled outputs of the three models are expected to reveal some of the complexities in the inter-related responses of groundwater and surface water flow systems to multi-decadal timescale changes in rainfall patterns.

Keywords: Groundwater modelling, Surface water modelling, Recharge modeling, climate change 


\section{INTRODUCTION}

To understand the potential impacts of changes in rainfall and potential evapotranspiration (PET), the dynamic interaction that exists between changes in surface runoff, groundwater recharge, and groundwater levels must be represented appropriately. Such a system can be modelled using fully coupled groundwatersurface water flow models, or using separate models that each are more specialised in their representation of recharge, groundwater or surface water processes.

It is more common in practice for separate models to be developed, due to the perceived difficulties in developing a fully-coupled model, owing to the data, software and computational requirements (Furman, 2008). Each of the individual models may be developed by a different team of experts, for different purposes at different times. Rarely are the assumptions, inputs and results of the different models compared in detail. Models have differing strengths and weaknesses in their representation of several of the water budget components, according to their primary area of interest (Sophocleous, 2002). For example, a surface water runoff model may include a term for streambed loss to the groundwater system, which is not affected by any consideration of the level of groundwater beneath the stream.

A methodology for reconciling the inputs and outputs of a surface water runoff model, groundwater recharge model and groundwater flow model was developed using the Cox Creek catchment (CCC) as a case study. This is a catchment in which surface water and groundwater systems are connected (Banks, 2010). Three models were developed for Cox Creek, simulating recharge, surface water and groundwater respectively.

This paper describes the three models and how the assumptions, inputs and outputs will be reconciled such that inter-linking components of the water budget are in agreement between models to improve the rigour in each model's representation of catchment processes.

The reconciled models will be used with stochastically-generated input data sets of rainfall and PET, representing a variety of possible future climate scenarios. Reconciled outputs of the three models are expected to reveal some of the complexities in the inter-related responses of groundwater and surface water flow systems to long-term changes in rainfall patterns.

\section{COX CREEK CATCHMENT}

The CCC is located in the Western Mount Lofty Ranges of South Australia (Figure 1). It covers a total area of $29.9 \mathrm{~km}^{2}$ and is a sub-catchment of the Onkaparinga River catchment. The catchment has steep topography varying in elevation from $700 \mathrm{~m}$ AHD (Australian Height Datum, where $0 \mathrm{~m}$ AHD is approximately mean sea level) at the northern boundary of the catchment to $320 \mathrm{~m}$ AHD at the southern boundary. The CCC is characterised by warm summers and cold, wet winters. It has an annual average rainfall of $1189 \mathrm{~mm} /$ year, occurring mainly between May and October (Banks, 2010). Surface drainage is from the higher northern boundary to the south-east where it discharges into the Onkaparinga River. The creeks within the catchment are typically 1 to $2 \mathrm{~m}$ wide and some reaches are ephemeral.

The steep slopes on the northern part of the catchment are heavily wooded, while central, flatter areas are used for agriculture, including irrigated crops. Water for irrigation is mainly sourced groundwater. Other features within the catchment include part of the Mount Lofty Botanic Gardens and the towns of Summertown and Uraidla.

The CCC aquifers are predominantly fractured rock aquifers (FRAs) and the regional groundwater flow direction in the FRAs is from the elevated areas at the edges of the catchment towards the Cox Creek at the topographically lower, central area of the catchment (Banks, 2010). Recharge to the FRAs of the CCC occurs primarily via direct rainfall recharge through thin soil profiles and via stream bed recharge in losing stream reaches of the Cox Creek and its tributaries, predominantly due to winter rainfall. Recharge flux rates are highly spatially variable, governed by a complex combination of rainfall duration and intensity, topography, vegetation type and extent, soil profile types and underlying geology.

The CCC provides surface water and groundwater for local domestic, industrial and agricultural use. As part of the Mount Lofty Ranges, it also contributes to metropolitan Adelaide's reticulated water supply (Stewart and Green, 2010). 


\section{COX CREEK HYDROLOGICAL MODELS}

\subsection{Recharge model}

In this study, the Leaching Estimation and Chemistry Model (LEACHM; Hutson, 2003) has been used to model recharge. LEACHM is a modelling platform that simulates the flux of water in variably-saturated conditions, such as through a soil profile above a water table. LEACHM uses a finite difference approximation of the Richards equation (Equation 1) (Richards, 1931) to model 1-dimensional vertical movement of water between specified layers within a soil profile, in response to water flux through the soil surface:

$$
\frac{\partial \theta}{\partial t}=-\frac{\partial}{\partial z}\left(K \frac{\partial H}{\partial z}\right) \quad \text { Equation } 1
$$

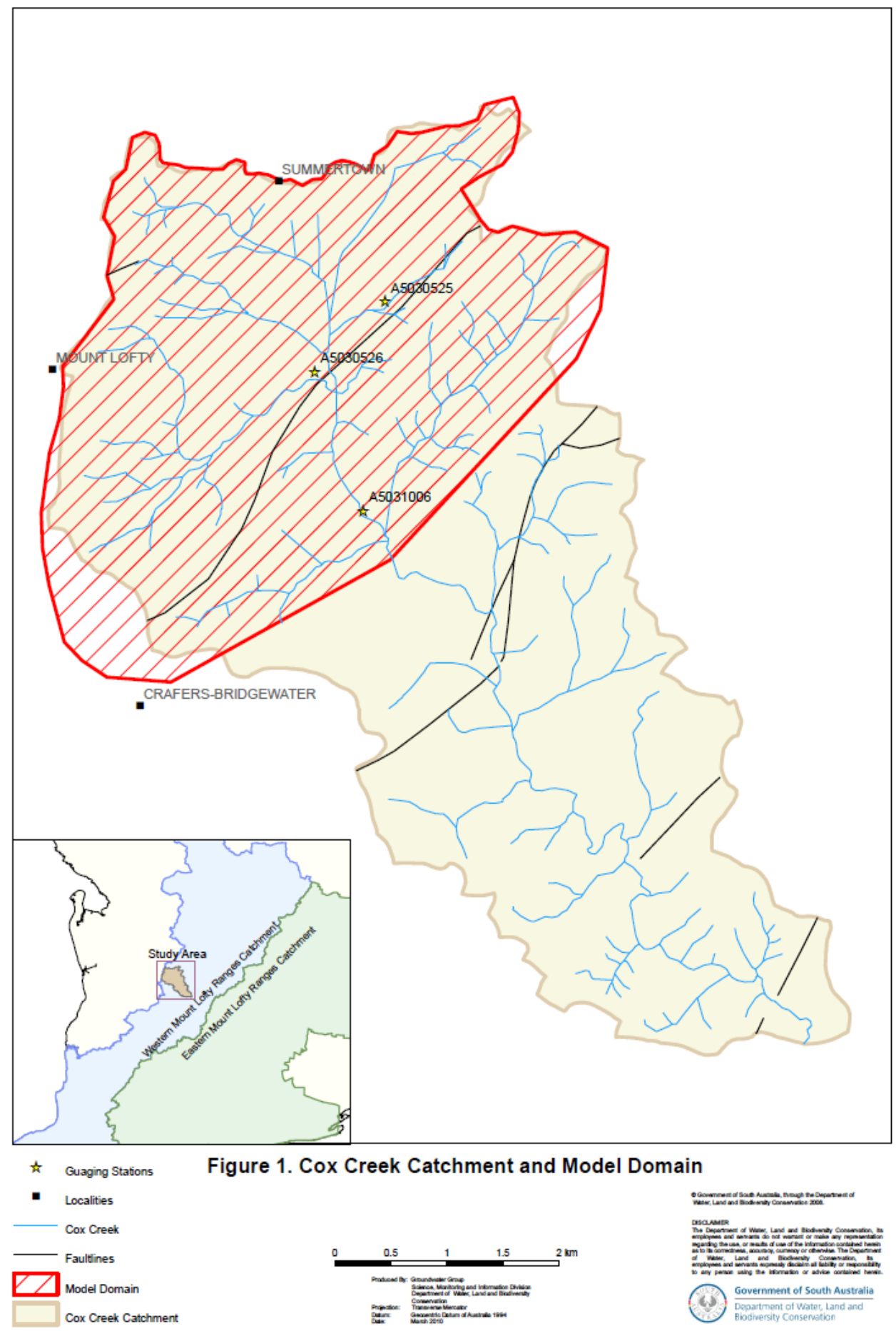

Figure 1. Cox Creek Catchment and model area (sourced from Stewart and Green, 2010). 
where $z$ is the vertical distance between nodes in the soil profile model and $t$ is the time increment, which has a maximum value of 0.1 days. $H$ is the total soil moisture head potential and is equal to $\operatorname{hm}(\theta)+z$, where $\operatorname{hm}(\theta)$ is the soil moisture matric potential at soil moisture content $\theta$.

In the LEACHM model of the CCC, the soil profile is represented as twenty soil layer segments, each of 10 $\mathrm{cm}$ thickness. For each layer, the water retention and unsaturated hydraulic conductivity functions are encoded in the model and parameter values for these functions are user-specified in the input data file (Green, 2010).

LEACHM allows a number of options for lower boundary condition. The option of free drainage was used in this study, which assigns a unit hydraulic gradient at the lowest node. The flux that passes the lowest node in the LEACHM model represents modelled groundwater recharge. The upper boundary of the model is the interface between the soil surface, crop and the atmosphere.

The input data for individual LEACHM simulations include records of rain and irrigation, PET and crop cover development. Rainfall and PET data for calibration of the Cox Creek LEACHM model were drawn from Bureau of Meteorology data sets (BoM, 2013) for stations within or adjacent to the model domain area. In LEACHM, the PET is split into potential evaporation and potential transpiration such that:

- Potential Transpiration, Tp = PET x vegetation cover fraction, and

- Potential Evaporation, Ep = PET $(1-$ vegetation cover fraction $)$

where the vegetation cover fraction refers to the growth and senescence of vegetation cover. The latter is simulated by a sigmoidal function that predicts vegetation cover fraction on each day of the simulation based on starting and end dates and the maximum and end-of-year vegetation cover specified by the user, and in this study, estimated from aerial photographs

\subsection{Surface water model}

SOURCE (previously Source IMS) is an integrated modelling software package developed by eWater Ltd as part of the National Hydrologic Modelling Platform (NHMP). SOURCE can model both catchments, to simulate the generation of runoff and associated water quality, as well as rivers, to account for the transport of water to support planning and river operations.

A Source IMS hydrological model (Delgado et al., 2012) was constructed for CCC using a catchment threshold of $0.2 \mathrm{~km}^{2}$. This small threshold value gave rise to $55 \mathrm{sub}$-catchments in the $16.4 \mathrm{~km}^{2}$ catchment. Hydrology at gauge AW5030526 was calibrated against flow during the period 1994 to 2012, using the GR4J rainfall runoff model in the calibration tool of Source IMS. The calibration gave a Nash-Sutcliffe efficiency value of 0.81 for daily flow. Total simulated flow over the simulation period was $14 \%$ less than observed flow. An efficiency value greater than 0.8 and \% difference of total flow less than $20 \%$ are generally considered to be a good fit for catchment modelling.

\subsection{Groundwater model}

The groundwater flow model of the CCC is an update of a previously developed model by Stewart and Green (2010). The CCC model encompasses the northern $15.64 \mathrm{~km}^{2}$ of the catchment (Figure 1). The groundwater flow modelling is carried out using MODFLOW2000 (Harbaugh et al., 2000). The model consists of two layers and a uniform grid size of $50 \mathrm{~m}$ in both horizontal directions. The top layer represents the unconfined fractured rock zone and the bottom layer a zone of reduced fracture pervasiveness. Both layers are $200 \mathrm{~m}$ thick. Monthly time steps are used as there are significant seasonal variations in potentiometric head. The model adopts 479 monthly stress periods, which follow a steady-state simulation as a surrogate for initial (i.e. pre-development) conditions. The transient model includes a 30-year calibration period of historical monthly data of recharge and groundwater extractions (i.e. from 1975 to 2004 inclusive), and the first 10 years (i.e. from 1965 to 1974 inclusive) of the transient period are modelled with the 30-year average monthly recharge and pumping to ensure the system reached steady state.

The model adopts an equivalent porous medium approach to simulating fractured rock aquifer. The model is divided into five hydrogeological zones based on geological data from borehole information (Stewart and Green, 2010): Aldgate Sandstone, Barossa Complex, Basket Range Sandstone, Stonyfell Quartzite, and Woolshed Flat Shale. The model conductivity zones align with the geological boundaries. Aquifer test 
estimates of hydraulic conductivity are available only for two geological areas (Woolshed Flat Shale and Aldgate Sandstone), and aquifer properties for the three remaining geological units were estimated based on literature. Regional groundwater flow is simulated using general head boundaries (GHBs) (Harbaugh et al., 2000) at the edges of model domain to represent flows into the domain from other catchments and outflow to the southern half of the catchment. Cox Creek is simulated using river cells.

The other model boundary conditions, including sources and sinks, represent fluxes which are also simulated by the recharge and surface water models. These are the groundwater model components which must be reconciled with the other models, as described in Section 4 below.

\section{RECONCILING THE MODELS}

The recharge and surface water models use the same climate data for simulations. For the "base case", the climate datasets are local observations from Bureau of Meteorology weather stations. For future climate scenarios, the datasets are generated by downscaling GCM projections to the same Bureau of Meteorology stations. Hence the recharge and surface water models employ the same assumptions about future changes in rainfall and PET.

Groundwater recharge estimated by the recharge and surface water models will be compared. The SOURCE model employs the GR4J rainfall runoff model in the catchment area of gauge A5020526, which calculates $100 \mathrm{~mm} /$ year over the simulation period. This is close to the aquifer recharge rate of $110 \mathrm{~mm} /$ year which was estimated from rates used in the groundwater model of Stewart and Green (2010) but needs to be compared with the revised estimates from the LEACHM recharge model.

Outputs from the recharge model are used as inputs for the groundwater model. The recharge model provides a net recharge for the watertable aquifer, including recharge from rainfall, recharge from irrigation and groundwater evapotranspiration, all of which are highly seasonal. LEACHM calculates the net recharge for every cell used by the groundwater model. The LEACHM calculations are daily but are averaged to provide values for each month at each grid location. The programming language $\mathrm{R}$ was used to develop a code to read the net monthly recharge for each cell from the LEACHM outputs files and reformat the information as a MODFLOW recharge file.

The recharge model also calculates the irrigation applied to meet crop requirements for various combinations of soil types, crop types, and slope. This is used to estimate well extraction volumes over time. As almost all of the extraction within the catchment is for irrigation, it is assumed that the volume extracted in a given month is equal to the irrigation requirements of the CCC. LEACHM does not provide the irrigation spatially by grid cell, another $\mathrm{R}$ code was developed to read the monthly application volumes for each soil and crop type, calculate the requirements for each irrigation area, then divide it between the nearby extraction wells. The code also automates the process of creating well extraction files which can be input into MODFLOW.

The surface water model outputs are used as calibration data in the groundwater model. The groundwater model calculates the flux between groundwater and the creek system over the same reaches defined in the surface water model. Model parameters, including river cell conductance, are varied during calibration.

As many different scenarios may need to be considered, it is important that the steps linking the models together be as automated as possible. This increases the accuracy and speed of the model setup.

\section{DISCUSSION AND FUTURE WORK}

Individual models of surface water runoff, groundwater recharge and groundwater flow have been developed to assess climate change impacts for a river sub-catchment in the Mount Lofty Ranges of South Australia. Reconciliation of the inputs and outputs of the three models with each other should improve the rigour in each model's representation of catchment processes.

Calibration of the transient model will be conducted with the nonlinear parameter estimation software PEST (Doherty, 2005). Hydrographs from eleven observation bores within the catchment and surface model outputs (see Section 4) will be used to evaluate model fit while adjusting aquifer parameters (i.e. storage parameters and hydraulic conductivities) and General Head Boundary (GHB) conductances.

The next step is to trial some possible climate change scenarios. Projections of future precipitation and (variables that enable calculation of) potential evapotranspiration have been downscaled using a Nonhomogeneous Hidden Markov Model (NHMM) (Kirshner, 2005). This model relates daily multi-site precipitation occurrences and amounts to a small discrete set of 'states' that, whilst they are constructs of the 
model, represent the dominant spatial patterns in rainfall across the network of stations (Charles et al., 2012). The daily transition between states follows a first-order Markov process that is conditional on a small set of atmospheric predictors, hence the prefix "nonhomogenous".

The reconciled models will be run with these stochastically-generated input data sets of rainfall and PET, representing a variety of possible future climate scenarios. The future projections for this study are to be generated from the CSIRO Mk 3.6 GCM, based on the RCP4.5 representative concentration pathway (Moss et al 2008). Reconciled outputs of the three models are expected to reveal some of the complexities in the inter-related responses of groundwater and surface water flow systems to long-term changes in rainfall patterns.

\section{ACKNOWLEDGMENTS}

The project is funded by the Goyder Institute for Water Research, as Task 4 of Project C.1.1: Development of an agreed set of climate change projections for South Australia. Dr Steve Charles of the CSIRO provided the climate change predictions for rainfall and potential evapotranspiration. The authors would like to thank Simone Stewart of the Department of Environment, Water and Natural Resources who provided assistance with the datasets compiled for the 2010 groundwater model. Dr John Hutson, Mr Matthew Knowling and Mr Carlos Miraldo were generous in their assistance with the LEACHM code.

\section{REFERENCES}

Banks E., 2010. Groundwater-surface water interaction in the Cox, Lenswood and Kresbrook Creek Catchments, Western Mount Lofty Ranges, South Australia. DWLBC report 2010/19, Government of South Australia, through Department for Water, Adelaide.

Bureau of Meteorology (BoM), 2013. NRM Enhanced Meteorological data sets (SILO) website, viewed February 2013, http://www.longpaddock.qld.gov.au/silo/

Charles S.P., Bates B.C., Hughes J.P., 2012. A spatiotemporal model for downscaling precipitation occurrences and amounts. Journal of Geophysical Research Atmospheres, 104, 31657-31669.

Delgado P., Kelley P., Murray N., Satheesh A., 2012. Source User Guide, eWater Cooperative Research Centre, Canberra, Australia.

Doherty J., 2005. PEST: Model Independent Parameter Estimation. Edition 5 of user manual. Watermark Numerical computing.

Furman A., 2008. Modeling coupled surface-subsurface flow processes; A review. Vadose Zone Journal, 7, $741-756$.

Green G., 2010. Point and regional scale modelling of vadose zone water and salt fluxes in an area of intensive horticulture, PhD Thesis, Flinders University of South Australia, 187 pp.

Harbaugh A.W., Banta E.R., Hill M.C., McDonald M.G., 2000. MODFLOW-2000, the U.S. Geological Survey modular groundwater model user guide to modularisation concepts and groundwater flow process. Denver, CO, Reston, VA: U.S. Geological Survey.

Hutson J.L., 2003. LEACHM: A process based model of water and solute movement, transformations, plant uptake and chemical reactions in the unsaturated zone. Department of Crop and Soil Sciences, Research Series No. R03-1, Cornell University, Ithaca, New York.

Kirshner S., 2005. Modeling of multivariate time series using hidden Markov models. PhD Thesis, University of California, Irvine, $202 \mathrm{pp}$.

Moss R., Babiker M., Brinkman S., Calvo E., Carter T., Edmonds J., Elgizouli I., Emori S., Erda L., Hibbard K., Jones R., Kainuma M., Kelleher J., Lamarque JF., Manning M., Matthews B., Meehl J., Zurek M., 2008. Towards New Scenarios for Analysis of Emissions, Climate Change, Impacts, and Response Strategies. Intergovernmental Panel on Climate Change, Geneva.

Richards L.A., 1931. Capillary conduction of liquids through porous medium, Physics, 1, 318-333. 
Woods et al., Reconciling surface and groundwater models

Sophocleous M., 2002. Interaction between groundwater and surface water: the state of the science. Hydrogeology Journal, 10, 52-67.

Stewart S., Green G., 2010. Groundwater flow model of Cox Creek Catchment, Mount Lofty Ranges, South Australia. DWLBC report 2010/14, Government of South Australia, through Department for Water, Adelaide. 